Reprod. Nutr. Dévelop., 1986, 26 (4), 989-998.

\title{
Cumulus oophorus mucification during resumption of meiosis in the pig. A scanning electron microscope study
}

\author{
J.-E. FLÉCHON $\left({ }^{1}\right)$, J. MOTLIK $\left({ }^{*}\right)$, R. H. F. HUNTER $\left({ }^{*}\right)$, Bernadette FLÉCHON, \\ J. PIVKO $\left({ }^{* *}\right)$, J. FULKA $\left(^{*}\right)$
}

Station de Physiologie animale, I.N.R.A., 78350 Jouy-en-Josas, France.

(*) Institute of Physiology and Genetics of Animals, Czechoslovak Academy of Science, 27721 Libechov, Czechoslovakia.

(**) School of Agriculture, University of Edinburgh, Edinburgh EH9 3JG. United Kingdom.

(***) Research institute of Animal Production, 94992 Nitra, Czechoslovakia.

\begin{abstract}
Summary. The process of cumulus mucification in pig preovulatory follicles was examined by scanning electron microscopy. The localization of extracellular material and changes in the granulosa cell surface were observed at $0,16,20$ and $40 \mathrm{~h}$ after hCG injection. At $0 \mathrm{~h}$ the pig oocyte cumulus complex was closely attached to the parietal layer of granulosa cells. Cumulus and parietal granulosa cells had microvilli and cytoplasmic projections connecting neighbouring cells. The network of extracellular amorphous material was observed for the first time at $16 \mathrm{~h}$ after hCG around the cells that formed a stalk between the parietal granulosa and the cumulus oophorus. At $20 \mathrm{~h}$ after hCG, the intercellular matrix was thicker and extended to almost all the cumulus oophorus surface ; when visible, cells were often covered by blebs and ruffling membranes. All oocytes examined by light microscopy at 16 and $20 \mathrm{~h}$ after hCG were at the germinal vesicle stage with condensing bivalents. Therefore, it was concluded that oocyte nuclear maturation started at the same time that a mucified peduncle was forming between the cumulus oophorus and the parietal granulosa. Shortly before ovulation ( $40 \mathrm{~h}$ after $\mathrm{hCG}$ ) the matrix material filled all intercellular spaces and mucification had extended to the corona cell layer and the zona pellucida surface.
\end{abstract}

\section{Introduction.}

Fully grown mammalian oocytes are still connected to the cumulus cells by gap junctions between the corona radiata processes and the oolemma (reviewed by Szöllösi and Gérard, 1983). These junctions are presumed to ensure metabolic cooperation, i.e. the exchange of small molecules between the parietal granulosa

(1) Postal address for correspondence: J.-E. Fléchon, I.N.R.A., Station de Physiologie animale, 78350 Jouy-en-Josas, France. 
cells, cumulus oophorus and the oocyte inside the antrum (Moor, Smith and Dawson, 1980).

The preovulatory LH peak initiates cumulus mucification, that is the deposition of a hyaluronidase-sensitive intercellular matrix (Schuetz and Schwartz, 1979 ; Eppig, 1980) ; this process is accompanied by the so-called expansion of the cumulus oophorus, the interruption of gap junctions (Anderson and Albertini, 1976) and a decreased metabolic cooperation between the cumulus cells and the oocyte (Gilula, Epstein and Beers, 1978 ; Moor et al., 1981). In fact, during in vivo maturation of mouse, sheep and pig oocytes, the sharpest decline in intercellular coupling between the oocyte and cumulus oophorus was only correlated with corona radiata expansion (Moor et al., 1981 ; Eppig, 1982 ; Motlik, Fulka and Fléchon, 1986).

Mucus deposition in the cumulus oophorus can be studied by scanning electron microscopy (SEM). In rats SEM observations demonstrated that the gradual accumulation of an extracellular matrix starts at about $5 \mathrm{~h}$ before ovulation (Dekel et al., 1978 ; Dekel and Phillips, 1979) ; 2 h before ovulation, the cumuli are completely coated by a hyaluronidase-sensitive matrix.

The aim of the present study was to use SEM to examine mucification of the pig oocyte-cumulus complex during in vivo maturation. The observations focused on the deposition of extracellular amorphous material and changes in parietal and cumulus granulosa cell surface configurations. The timing of these events was compared with the process of nuclear maturation and changes in intercellular communications (Motlik et al., 1986).

\section{Material and methods.}

Prepubertal gilts of the Large White breed about 6 months old were stimulated by $1000 \mathrm{IU}$ of PMSG (Antex, Leo, Copenhagen); $72 \mathrm{~h}$ later, $1000 \mathrm{IU}$ of hCG (Praedyn, Spofa) were injected. Immediately after slaughter at 0, 16, 20 or $40 \mathrm{~h}$ after hCG injection, the ovaries of two gilts for each time were excised and placed in pre-warmed PBS. The wall of the large preovulatory follicles was opened under a dissecting microscope and the oocyte-cumulus cell complexes

PLATE 1. - Cumulus oophorus (CO) at $O \mathrm{~h}$ after hCG (left) and at $16 \mathrm{~h}$ after hCG (right).

FIG. a. - Low magnification of the $\mathrm{CO}$ in close contact with the parietal granulosa of the follicle. $\times 200$.

FIG. $\mathrm{b}-$ General aspect of the granulosa cells of the $\mathrm{CO}$ and surrounding follicular wall. $\times 900$.

FIG. c. - Parietal granulosa cells. The $\mathrm{CO}$ cells have large cytoplasmic connecting projections and short microvilli. $\times 4,000$.

FIG. d. - Low magnification of the $\mathrm{CO}$; it is connected to the follicular wall by a short stalk covered with mucus $(-1 . \times 80$.

FIG. e. - General aspect of the CO partly embedded in mucous material, but less so than the salk. $\times 360$.

FIG. f. - Cells of the CO surrounded by extracellular matrix still show some connecting projections. $\times 4,600$ 

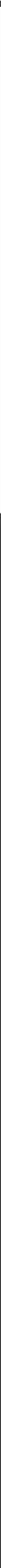
with the adjacent part of the parietal granulosa were isolated with fine stainless steel needles. The nuclear maturation of about 20 oocytes (controls) from each group was examined by phase-contrast microscopy. In each of two experiments, 10 oocyte-cumulus complexes were fixed in $2.5 \%$ glutaraldehyde in cacodylate buffer at $\mathrm{pH}$ 7.2. The specimens were dehydrated in alcohol, critical-point dried in freon 13 and coated with gold. They were observed at $15 \mathrm{KV}$ in an Hitachi S 450 scanning electron microscope.

Some cumuli oophori or oocytes were also recovered from untreated cyclic gilts at periods estimated a few hours before or after expected ovulation time. The onset of oestrus was detected twice a day (9 am and $4 \mathrm{pm})$ with a teaser boar. In the first case, part of the cumulus cells was mechanically removed in order to allow observation of corona radiata cells and of the zona pellucida. The specimens were prepared as above.

\section{Results.}

The pig oocyte-cumulus complex isolated from preovulatory follicles at $72 \mathrm{~h}$ after PMSG $(0 \mathrm{~h}$ after hCG) was closely attached to the parietal granulosa cells (PI. 1, figs $a, b)$. The rounded or oblong cumulus cell had microvilli and large cytoplasmic projections connecting the neighbouring cells (PI. 1, fig. c.).

AT $16 \mathrm{~h}$ after hCG, when the first symptoms of cumulus expansion were visible under the dissecting microscope, the oocyte-cumulus complex was no longer closely attached to the parietal granulosa (PI. 1, figs $d$, e). The fine network of extracellular amorphous material was localized mainly around the cells that formed a stalk between the parietal granulosa and the cumulus oophorus; this material was also seen between cells of the cumulus oophorus itself (PI. 1, fig. f). At $20 \mathrm{~h}$ after hCG, the stalk was longer $(>1 \mathrm{~mm})(\mathrm{PI}$. 2, fig. a) and the intercellular matrix thicker (PI. 2, figs $\mathrm{b}, \mathrm{c}$ ). It was still possible to see islands of cells on the cumulus oophorus, whereas the extracellular matrix was found in deeper layers (PI. 2, fig. d). Peripheral cumulus cells were rounded without large connecting projections and, as also noticed first in the previous stage, the surface of many cells was covered by bulbous protrusions or blebs and ruffling membranes (PI. 2, figs e, f).

All control oocytes fixed at 16 and $20 \mathrm{~h}$ had a germinal vesicle with more or less condensed filamentous bivalents. Thus, during in vivo maturation of pig

PLATE 2. - Cumulus oophorus at $20 \mathrm{~h}$ after hCG.

FIG. a. - Low magnification of the $\mathrm{CO}$ on the tip of a long stalk. $\times 80$.

FIGS b. c. - The stalk is embedded in a thick layer of mucous material from which a few cells emerge. b: stalk itself. $\times 1,000$.

c: close to CO. $\times 2,500$.

FIG. d. - Group of superficial CO cells (some of them mechanically removed) showing blebs and surrounded by extracellular matrix. $\times 2,000$.

FIGS e, f. - Higher magnification of $\mathrm{CO}$ cells displaying a very heterogeneous morphology (microvilli, blebs, ruffling membranes). $\times 5,500$. 
oocytes, mucus was deposited at least between the peripheral cumulus cells before germinal vesicle breakdown (20-24 h after hCG).

The viscosity of the mucus is illustrated on cumulus material recovered around $10 \mathrm{~h}$ before ovulation (PI. 3, fig. a). At $40 \mathrm{~h}$ after $\mathrm{hCG}$, while all the control oocytes had extruded the first polar body, the fully expanded cumulus cell-oocyte complex escaped with the fluid contents when the follicular cavity was opened. The cumuli were completely coated with the extracellular material (PI. 3, fig. b).

Dissection of the cumulus oophorus around $10 \mathrm{~h}$ before ovulation revealed almost no mucification of the corona radiata ( $\mathrm{PI} .3$, figs $\mathrm{b}, \mathrm{c}$ ), whereas its expansion started around $30 \mathrm{~h}$ after hCG. However, on newly-ovulated oocytes, the extracellular matrix was visible between the corona radiata cells and on the surface of the zona pellucida (PI. 3, figs e-f).

\section{Discussion.}

Apart from occasional cytoplasmic projections, the pig granulosa cells of small antral follicles $(1-2 \mathrm{~mm})$ are generally round and smooth. The granulosa cell surface of large follicles $(6-12 \mathrm{~mm}$ ) is covered with microvilli (Chang et al., 1977). Our SEM observations of pig preovulatory follicles at $72 \mathrm{~h}$ after PMSG also showed the presence of microvilli on cumulus and parietal granulosa cells. The cytoplasmic bridges between cumulus cells, most frequently observed at $0 \mathrm{~h}$ after hCG in our material, may be the morphological counterpart of the completely functional connection between cumulus cells at that time.

The modifications of the granulosa cell surface during the growth phase of pig antral follicles may be linked to changes in cell surface gonadotropin receptors. While granulosa cells from small pig follicles contain only 300-400 LH receptors per cell, the number of these receptor sites in large follicles increases to 800-1,000 per cell (Lee, 1976). Thus, the appearance of microvilli coincides with an increase in the number of $\mathrm{LH}$ receptors. On the other hand, LH and hCG induce a decrease in the $\mathrm{FSH}$ and $\mathrm{LH}$ receptors of luteinizing granulosa cells (Rao et al., 1977). Changes in receptor content may thus represent a first step in the morphological alteration of the granulosa cell membrane induced by LH or hCG. In rats, SEM observations have revealed bulbous protrusions on parietal and

PLATE 3. - Cumulus oophorus and corona radiata around ovulation.

FIG. a. - About $10 \mathrm{~h}$ before ovulation, the mucus of the CO is already very viscous and forms filaments when cells are mechanically removed. $\times 100$.

FIG. b. $-40 \mathrm{~h}$ after $h C G$, the $C O$ is completely surrounded by a thick layer of mucus. $\times 1,500$.

FIG. c. - Corona radiata cells on the surface of the zona pellucida after partial removal of the CO, $\leq 10 \mathrm{~h}$ before ovulation. $\times 2,000$.

FIG. d. - Detail of the zona surface showing a pyriform corona cell still connected by a cytoplasmic process. A little extracellular matrix if any. $\times 4,000$.

FIGS e, f. - Corona cells and zona surface surrounded by filaments of extracellular matrix shortly after ovulation $(\leq 2 \mathrm{~h}) . \times 2,000$. 

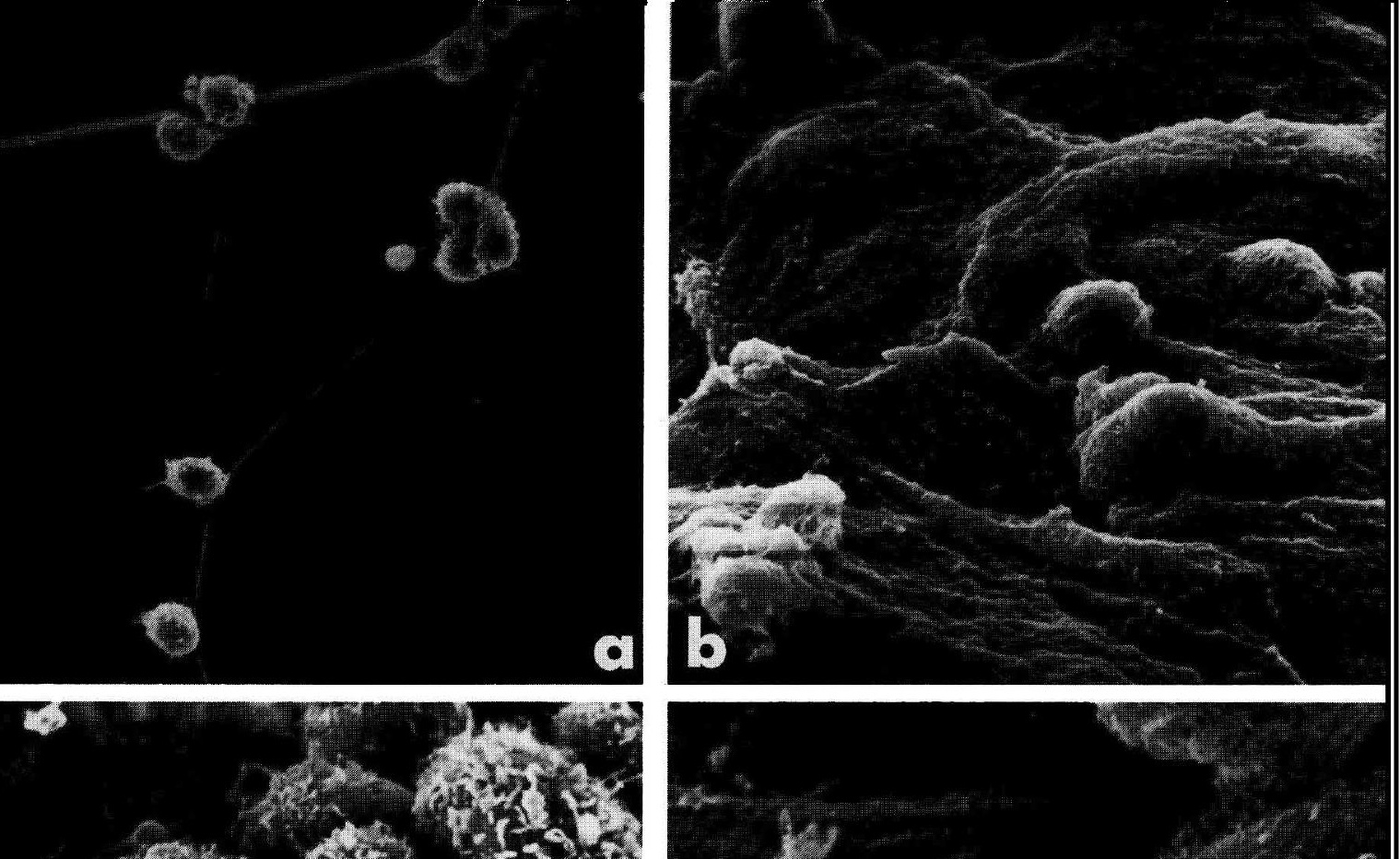

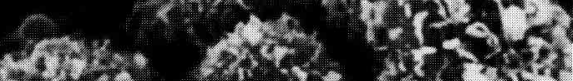
?

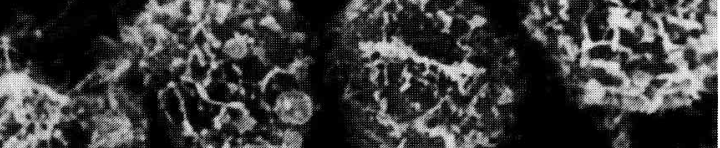
45

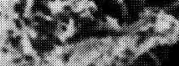
ats

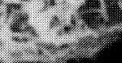
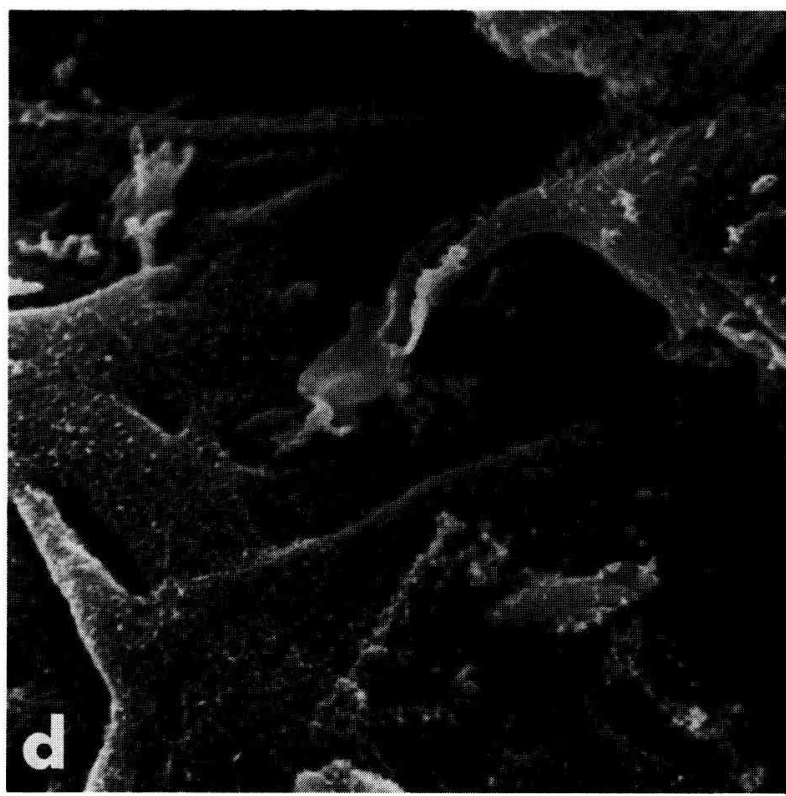

3.

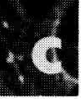
rest.

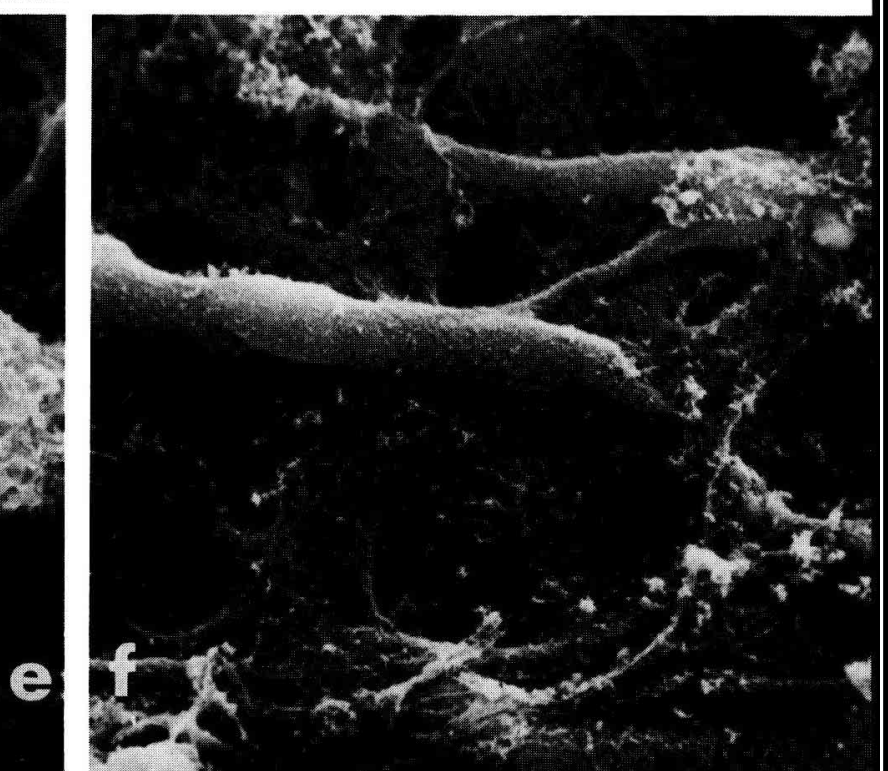


cumulus granulosa cells $6 \mathrm{~h}$ after hCG injection (Bagavandoss and Midgley Jr., 1981) ; cumulus cell blebbing has been noticed 2-3 h before expected ovulation (Dekel and Phillips, 1979) as well as in post-ovulatory rat cumuli (Dekel et al., 1978 ; Dekel and Phillips, 1979). In the present study, pig granulosa cells covered with blebs were first found in the superficial layers of the cumulus $16-20 \mathrm{~h}$ after hCG, when the intercellular spaces were enlarged by the presence of the mucous matrix. Under in vitro conditions, the blebbing on all the surfaces was observed concomitantly with the accumulation of extracellular material, when rat cumuli were cultured in the presence of LH and FSH (Dekel and Phillips, 1979). Rat granulosa cells exposed to $\mathrm{LH}$ and cultured in vitro lost their microvilli but showed prominent, grouped blebs (Bernard and Chretien, 1978). All these data indicate that these superficial morphological changes may express granolosa cell membrane differentiation during luteinization.

SEM clearly demonstrates the onset of mucification. Mucus is first deposited in rat cumuli about $5 \mathrm{~h}$ before expected ovulation (Dekel and Phillips, 1979). The fine network of extracellular material is observed about $24 \mathrm{~h}$ before ovulation in pigs, that is relatively earlier (respective maturation times : 12 and $40 \mathrm{~h}$ ). The intercellular matrix is observed mainly on the stalk between the parietal granulosa and the cumulus oophorus. $20 \mathrm{~h}$ after hCG, this matrix not only surrounds the superficial layers but also the deeper layers of cumulus granulosa cells. Briefly, cumulus mucification starts in the stalk appearing between the parietal and cumulus granulosa cells and then continues from the superficial layers of cumulus cells to the deeper ones, during the time the bivalents have condensed. These observations infer that initiation of oocyte nuclear maturation in pig preovulatory follicles is associated with a gradual loss of morphological and probably functional connections between the cumulus oophorus and the follicular wall. Indeed, as the uptake of ${ }^{3} \mathrm{H}$-uridine by cumulus-enclosed pig oocytes is very high up to $24 \mathrm{~h}$ after hCG and, as a significant decrease of the coupling index occurs only at $32 \mathrm{~h}$ after hCG (Motlik et al., 1986), it can be concluded that the functional connection between the corona radiata cells and the oocyte is interrupted later ( $\geq 32 \mathrm{~h}$ after hCG) than it is between the cumulus oophorus and the follicular wall (probably 16-20 $\mathrm{h}$ after $\mathrm{hCG}$ ).

Mucification of the corona radiata clearly occurs only in mature oocytes where the coupling index between the oocyte and the surrounding cell layer is minimal (Motlik et al., 1986). The filamentous network of the extracellular matrix appears to be associated with the surface of the zona pellucida, as also observed by transmission electron microscopy in pigs (Fléchon et al., 1986) and other species (Talbot and Dicarlantonio, 1984). Note that expansion in the different parts of the cumulus oophorus as observed by light microscopy corresponds in all cases to mucification as observed by SEM, except for the corona radiata where mucus deposition may be slow and less abundant.

Colloque franco-tchécoslovaque,

I.N.R.A., Jouy-en-Josas, 5-6 décembre 1984.

Acknowledgements. - We thank Mr. J. Surel for taking care of the oestrus tests, $\mathrm{Mr}$. R. Scandolo for printing the plates and Mrs A. Daifuku for editing the text. 
Résumé. Mucification du cumulus oophorus pendant la reprise de la méiose chez la truie. Etude en microscopie électronique à balayage.

La mucification du cumulus oophorus d'ovocytes préovulatoires de truie est examinée au microscope électronique à balayage. Le dépôt de matrice extracellulaire et les modifications morphologiques cellulaires sont observées à $0,16,20$ et $40 \mathrm{~h}$ après l'injection d'hCG. Au temps 0 , le cumulus oophorus est étroitement attaché à la paroi du follicule. Les cellules du cumulus et de la paroi possèdent des microvillosités et des projections cytoplasmiques qui connectent les cellules voisines. Un fin réseau de matériel extracellulaire est visible $16 \mathrm{~h}$ après hCG, localisé principalement entre les cellules qui constituent maintenant un pédoncule entre la paroi et le cumulus oophorus. $A 20 \mathrm{~h}$ après hCG, la matrice intercellulaire est plus épaisse et s'étend à peu près sur tout le cumulus oophorus ; lorsqu'elle est visible, la surface des cellules du cumulus oophorus est très irrégulière. Tous les ovocytes, examinés en microscopie photonique 16 et $20 \mathrm{~h}$ après hCG, sont au stade de la vésicule germinative. La mucification débute donc avant la rupture de la vésicule germinative et la maturation nucléaire apparaît consécutive au relâchement des rapports entre le cumulus oophorus et la paroi du follicule. Peu avant l'ovulation, le mucus remplit tous les espaces intercellulaires et s'étend jusqu'à la corona radiata et la surface de la zone pellucide.

\section{References}

ANDERSON E., ALBERTINI D. F., 1976. Gap junctions between the oocyte and companion follicle cells in the mammalian ovary. J. Cell Biol., 71, 680-686.

BAGAVANDOSS P., MIDGLEY Jr. A. R., 1981. Bleb formation in granulosa cells of rat preovulatory follicles in vivo and in vitro. Tissue Cell, 13, 669-680.

BERNARD J., CHRETIEN F. C., 1978. Effect of follicular fluid on the surface ultrastructure of rat granulosa cells in vitro. Biol. Reprod., 19, 133-143.

CHANG S. C. S., ANDERSON W., LEWIS J. C., RYAN R. J., KANG Y. H., 1977. Porcine ovarian follicles. II. Electron microscopy study of surface features of granulosa cells at different stages od development. Biol. Reprod., 16, 349-357.

DEKEL N., KRAICER P. F., PHILLIPS D. M., SANCHEZ R. S., SEGAL S. J., 1978. Cellular association in the rat oocyte-cumulus cell complex: Morphology and ovulatory change. Gamete Res., 1, 47-57.

DEKEL N., PHILLIPS D. M., 1979. Maturation of the rat cumulus oophorus : a scaning electron microscopic study. Biol. Reprod., 21, 9-18.

EPPIG J. J., 1980. Regulation of cumulus oophorus expansion by gonadotropin in vivo and in vitro. Biol. Reprod., 23, 545-552.

EPPIG J. J., 1982. The relationship between cumulus cell-oocyte coupling, oocyte meiotic maturation, and cumulus expansion. Dev. Biol., 89, 268-272.

FLECHON J.-E., KOPECNY V., MOTLIK J., PAVLOK A., 1986. Origin, structure and texture of the zona pellucida of mammalian eggs (Abstr.). Histochem. J., 18, 138.

GILULA N. B., EPSTEIN M. L., BEERS W. H., 1978. Cell-to-cell communication and ovulation. A study of the cumulus-oocyte complex. J. Cell Biol., 78, 58-75.

LEE C. Y., 1976. The porcine ovarian follicle: III. Development of chorionic gonadotropin receptors associated with increase in adenylate cyclase activity during follicle maturation. Endocrinology, 99, 42-48.

MOOR R. M., OSBORN J. C., CRAN D. G., WALTERS D. E., 1981. Selective effects of gonadotrophins $\mathrm{c}$ : cell coupling, nuclear maturation and protein synthesis in mammalian oocytes. $J$. Embryol. exp. Morph., 61, 347-365. 
MOOR R. M., SMITH M. W., DAWSON R. M. C., 1980. Measurement of intercellular coupling between oocytes and cumulus cells using intracellular markers. Exp. Cell Res., 126, 15-29.

MOTLIK J., FULKA J., FLECHON J.-E., 1986. Changes of intercellular coupling between pig oocytes and cumulus cells during in vivo and in vitro maturation. J. Reprod. Fert. 76, 31-37.

RAO M. C., RICHARDS J. S., MIDGLEY Jr. A. R., REICHERT Jr. L. E., 1977. Regulation of gonadotropin receptors by luteinizing hormone in granulosa cells. Endocrinology, 101, 512523.

SCHUETZ A. W., SCHWARTZ W. J., 1979. Intra-follicular cumulus cell transformation associated with oocyte maturation following gonadotropin hormone stimulation of adult mice. J. exp. Zool., 207, 399-406.

SZÖLLÖSI D., GERARD M., 1983. Cytoplasmic changes in the mammalian oocytes during the preovulatory period. In : BEIER H. M., LINDNER H. R., Fertilization of the human egg in vitro. Springer, Berlin, pp. 35-55.

TALBOT P., DICARLANTONIO G., 1984. The oocyte cumulus complex: ultrastructure of the extracellular components in hamster and mice. Gamete Res., 10, 127-142. 